\title{
SOSIALISASI KEDALAMAN YANG OPTIMAL BAGI PERTUMBUHAN DAN KUALITAS RUMPUT LAUT Eucheuma cottonii DI DESA EKAS BUANA KABUPATEN LOMBOK TIMUR
}

\author{
Nanda Diniarti*), Dewi Nur'aeni Setyowati, Ayu Adhita D., M. Junaidi, Ibadur Rahman \\ Program Studi Budidaya Perairan, Universitas Mataram. \\ Jl. Pendidikan Nomor 37, Mataram, 83125 \\ *korespondensi: nanda_unram@yahoo.co.id
}

\begin{abstract}
ABSTRAK
Teluk ekas merupakan sentra budidaya perikanan yang ada di pulau Lombok. Ekas buana merupakan salah satu desa yang berbatasan wilayahnya dengan Teluk Ekas. Mayoritas masyarakat Desa Ekas buana merupakan para pembudidaya rumput laut jenis Eucheuma cottonii. Dimana Keterampilan budidaya rumput laut didapatkan secara otodidak dan terun temurun sehingga sebagian besar tidak mengerti tentang teknik budidaya yang baik dan benar. Oleh karena itu perlunya masyarakat Desa Ekas Buana diberikan penambahan ilmu budidaya rumput laut. Kegiatan pengabdian ini dilaksanakan selama 3 bulan. Masyarakat sasaran adalah para pembudidaya rumput laut di Desa Ekas Buana Kecamatan Jerowaru. Metode yang digunakan adalah pendidikan orang dewasa. Berdasarkan hasil kegiatan pengabdian yang telah dilaksanakan maka dapat disimpulkan kegiatan penyuluhan dengan tema pengkayaan pengetahuan pembudidaya rumput laut tentang kedalaman yang optimal bagi pertumbuhan dan kualitas rumput laut Eucheuma cottonii di Desa Ekas Buana lombok timur telah menambah pengetahuan mereka akan kedalaman optimal untuk budidaya rumput laut yang baik agar dapat menghasilkan kualitas yang baik. Selain itu masyarakat disadarkan bahwa perilaku menjaga kelestarian dan kebersihan pantai akan mendukung kegiatan budidaya yang mereka lakukan.
\end{abstract}

Kata kunci: teluk ekas, budidaya rumput laut, kedalaman optimal

\section{PENDAHULUAN}

Nusa Tenggara Barat (NTB)

merupakan salah satu daerah yang memiliki potensi untuk pengembangan budidaya rumput laut terutama pada pulau Lombok. Berdasarkan data Statistik Dinas Kelautan dan Perikanan Provinsi NTB tahun 2013, memiliki potensi lahan budidaya rumput laut seluas 25.206 ha.
Teluk Ekas merupakan salah satu teluk yang memiliki aktivitas budidaya rumput laut yang tiap tahunnya tetap berproduksi. Luas Teluk Ekas 5.313 ha dengan panjang garis pantai $44 \mathrm{~km}$ (Radiarta et al., 2003). Teluk Ekas dikelilingi beberapa desa. Desa Ekas Buana adalah desa yang berbatasan dengan Teluk Ekas dan merupakan salah satu sentra 
budidaya rumput laut di Kecamatan Jerowaru Kabupaten Lombok Timur.

Penduduk Ekas Buana sebagian besar merupakan pembudidaya rumput laut. Keahlian budidaya didapatkan secara otodidak dan turun-temurun sehingga cara budidaya dilakukan karena kebiasaan di lapangan. Kurangnya keahlian ini menyebabkan kualitas dan kuantitas produksi kurang maksimal.

Selama ini pembudidaya belum memaksimalkan luas kolom air vertikal dan tidak mengetahui kedalaman yang optimal untuk digunakan pada budidaya rumput laut. Salah satu metode yang bisa memaksimalkan luasan kolom tersebut adalah menggunakan metode susun tingkat/ verticulture.

Salah satu faktor yang sangat penting dalam budidaya rumput laut adalah kedalaman penanaman. Kedalaman penanaman rumput laut perlu diperhatikan karena kedalaman akan mempengaruhi pertumbuhan rumput laut serta jumlah rendemen karaginan. Namun factor kedalaman penanaman relative tiap perairan. Pada perairan yang memiliki kecerahan tinggi maka posisi rumput laut akan relative dalam dibanding dengan perairan yang keruh.

Informasi tentang kedalaman penanaman rumput laut ini masih hanya konsumsi peneliti dan jarang di sosialisasikan dengan pembudidaya. Dari penelitian Majid (2018), didapatkan kedalam optimal adalah $35 \mathrm{~cm}$. Penelitian tersebut mendapatkan fakta bahwa penanaman pada kedalaman tersebut memiliki keutamaan dibanding kedalam lainnya. Hasil panen menambah 5\% dan jumlah rendemen karagenan bertambah bila dibanding dengan kedalaman yang selama ini pembudidaya lakukan. Oleh karena itu hasil penelitian ini harus disosialisasikan agar pembudidaya mengetahui dan mau mengikti hasil penelitian tersebut.

Pengabdian Pada Masyarakat bertujuan untuk meningkatkan pemahaman pembudidaya rumput laut di Desa Ekas Buana akan kedalaman optimal pada pembudidayaan rumput laut dan meningkatkan kesadaran penduduk akan kebersihan sekitar pantai. Manfaat yang dapat diambil dari kegiatan ini adalah peningkatan pengetahuan pembudidaya akan teknik budidaya rumput laut yang baik dan benar sehingga kegiatan budidaya dapat berjalan optimal dan menghasilkan hasil yang maksimal serta berkelanjutan.

\section{METODE KEGIATAN}

Pendekatan pelaksanaan kegiatan yang ditawarkan untuk program Pengabdian 
Pada Masyarakat (PPM) sebagai solusi dari permasalahan yang dihadapi adalah: penyuluhan kelompok masyarakat pembudidaya rumput laut khususnya dan masyarakat Ekas Buana tentang Alikasi teknologi pada budidaya ruput laut (kedalaman optimal) di perairan Ekas Buana dan peningkatan kesadaran masyarakat akan menjaga kelestarian kebersihan lingkungan pantai untuk menyokong budidaya rumput laut. Adapun rincian masing-masing kegiatan tersebut adalah sebagai berikut :

\section{Penyuluhan Kelompok Masyarakat}

Dalam meningkatan pengetahuan dan pemahaman kelompok masyarakat sasaran kedalaman optimal dalam pembudidayaan rumput laut di perairan Ekas Buana dan peningkatan kesadaran masyarakat akan menjaga kebersihan lingkungan pantai untuk menyokong budidaya rumput laut. Materi penyuluhan yang diberikan antara lain pembagian kedalaman perairan dan pemaparan hasil penelitian dari Majid (2018), dan peningkatan kesadaran masyarakat akan menjaga kebersihan lingkungan pantai untuk menyokong budidaya rumput laut. Penyuluhan dilaksanakan dengan menggunakan metode Pendidikan Orang Dewasa (POD) dengan penekanan pada model komunikasi dua arah dengan pola tukar menukar pengalaman, diskusi kelompok, dan demonstrasiyang dilaksanakan dalam bentuk klasikal. Sedangkan untuk meningkatkan pengetahuan psikomotorik sasaran dilaksanakan praktek secara mandiri di luar kelas.

\section{Pembinaan}

Pembinaan yang dilakukan meliputi pembinaan meliputi aspek budidaya rumput laut dan pelestarian dan kebersihan lingkungan. Salah satu bentuk pembinaan adalah pemantauan aktivitas masyarakat saat masa budidaya dan focus group discussion tentang hambatan penerapan materi dan teknologi yang diberikan.

\section{HASIL DAN PEMBAHASAN}

Kegiatan pengabdian ini merupakan deseminasi hasil penelitian yang telah dilakukan pada perairan Teluk Ekas bagian Desa Ekas Buana. Desa Ekas Buana merupakan salah satu desa binaan Universitas Mataram khususnya Program Studi Budidaya Perairan sehingga banyak penelitian dan pengabdian kepada masyarakat dilaksanakan disana.

Untuk terlaksananya kegiatan pengabdian kepada masyarakat maka perlu meminta izin pelaksanaandan koordinasikan kegiatan pada aparat desa. Setelah izin didapatkan maka tim pelaksana bertukar fikiran tentang hari pengabdian dengan 
ketua Kelompok Nelayan Pasir Putih. Hasil tukar fikiran disepakati tanggal 30 Juni 2018 sebagai pelaksanaan pengabdian.

Pelaksanaan pengabdian terlaksana sesuai dengan rencana yang telah dibuat. Pelaksanaan dilakukan di pinggir pantai karena aula Kantor Desa sedang dalam perbaikan. Kegiatan pengabdian dihadiri oleh 27 orang baik bapak-bapak dan Ibu-ibu yang merupakan pembudidaya rumput laut jenis Eucheuma cottonii.

Masyarakat Desa Ekas Buana hidupnya dekat sekali denga laut. Dimana pencaharian utama dan tambahan berhubungan dengan laut. Kegiatan yang umum dilakukan oleh masyarakat Desa Ekas Buana adalah pembudidayaan Rumput Laut .Kegiatan budidaya berfungsi sebagai mata pencaharian utama maupun sampingan.

Materi yang disampaikan pada pengabdian ini adalah sebagai berikut:

1. Aplikasi teknologi budidaya rumput laut (kedalaman optimal)

Awal materi dilakukan sampling cepat tentang cara budidaya rumput laut yang dilaksanakan di Ekas Buana. Tujuannya untuk melihat pengetahuan teknis budidaya rumput laut yang dimiliki masyarakat. Dari hasil sampling hampir semua peserta memiliki pengetahuan yang cukup untuk melakukan budidaya rumput laut yang baik. Setelah itu dilakukan pemaparan hasil penelitian yang telah dilakukan oleh Majid (2018). Hasil yang dari penelitian Majid menyatakan bahwa perairan Ekas mempunyai kedalaman budidaya rumput laut optimal pada kedalaman $35 \mathrm{~cm}$ baik dilihat dari pertumbuhan dan kandungan karagenan. Hal ini dikarenakan kecerahan perairan Pantai Desa Ekas Buana yang tinggi (>5 m) dan ditunjang oleh mencukupinya nutrient.

Jika melihat hasil penelitian tersebut, maka dimungkinkan budidaya rumput laut dilakukan secara vertikultur atau memanfaatkan kolom air secara maksimal. Penelitian Pongarrang et al. 2013 pada perairan Konawe memberikan hasil terbaik pertumbuhan mutlak yang jarak bibit tanam $40 \mathrm{~cm}$.

Tabel 1. Pertumbuhan rumput laut E. Cottonii di kedalaman berbeda

\begin{tabular}{lcc}
\hline \multicolumn{1}{c}{ Perlakuan } & Pertumbuhan Mutlak & Rendemen Karagenan \\
\hline Kontrol $(5 \mathrm{~cm})$ & $523,33^{\mathrm{c}} \pm 1,61$ & $12 \%$ \\
P1 $(15 \mathrm{~cm})$ & $543,34^{\mathrm{b}} \pm 1,67$ & $17 \%$ \\
P2 $(35 \mathrm{~cm})$ & $647,83^{\mathrm{a}} \pm 2,89$ & $24 \%$ \\
P3 $(75 \mathrm{~cm})$ & $474,92^{\mathrm{d}} \pm 1,73$ & 19 \\
\hline
\end{tabular}


2. Melestarikan kebersihan lingkungan pantai untuk menyokong budidaya rumput laut.

Berdasar nilai kimianya, Teluk Ekas telah berkriteria tercemar sedang sampai berat berdasarkan Junaidi (2016). Dampak pencemaran kimia akan diperparah jika ditambah dengan masukan limbah domestic masyarakat pesisir pantai. Beberapa perilaku merusak kelestarian pantai adalah: melakukan perikanan tangkap yang merusak seperti bom ikan, pembuangan sampah di badan air pantai, dan adanya limbah minyak yang berasal dari perahu/kapal. Namun Teluk Ekas di bagian Desa Ekas Buana memiliki perairan yang memiliki kecerahan yang relative tinggi yaitu $>5 \mathrm{~m}$. Perairan pantai masih sangat jernih dan masih banyak ditemukan kawanan ikan kecil di pinggir pantai. Ini menunjukkan bahwa perairan masih dalam kondisi alaminya. Jika ada masukan bahan organic dari kegiatan budidaya rumput laut atau ikan masih bisa ditolerir olah lingkungan.

Penyampaian materi dilakukan dengan dua arah yaitu berupa ceramah dan diskusi. Penilaian terhadap keberhasilana kegiatan pengabdian masyarakat ini dilakukan dengan berpedoman pada :

1. Kehadiran dan partisipasi peserta sampai berakhirnya penyuluhan merupakan cerminan dari keingintahuan terhadap materi yang dibawakan.

2. Banyaknya tanggapan baik berupa pertanyaan maupun pernyataan bahwa mereka membutuhkan informasi teknis dan non teknis tentang budidaya rumput laut.

3. Adanya pengetahuan dasar yang mereka miliki dan dipaparkan sebagai masukan pada penyaji seperti musim baik untuk budidaya rumput laut.

Adanya pemaparan hasil penelitian dan teknologi yang mungkin diterapkan oleh petani rumput laut dapat memberikan kesadaran lebih pada mereka bahwa lingkungan yang telah mereka jaga kelstarian dan kebersihannya memberikan imbal balik melalui hasil panen yang baik. Pengalaman yang dilakukan oleh mereka sendiri akan lebih kuat untuk tetap lestari disbanding penyadaran yang berasal dari orang lain/ luar.

Kegiatan pendampingan agak terhambat pada kegiatan ini dikarenakan Bencana Gempa yang terjadi. Desa Ekas Buana sendiri tidak terkena dampak yang parah namaun anggota pengabdian yang berdomisili di mataram yang terdampak. Pendampingan dilaksanakan setelah kondisi stabil yaitu pada bulan Oktober. 


\section{KESIMPULAN DAN SARAN}

Berdasarkan hasil kegiatan pengabdian yang telah dilaksanakan maka dapat disimpulkan kegiatan penyuluhan dengan tema pengkayaan pengetahuan pembudidaya rumput laut tentang kedalaman yang optimal bagi pertumbuhan dan kualitas rumput laut Eucheuma cottonii di Desa Ekas Buana lombok timur telah menambah pengetahuan mereka akan kedalaman optimal untuk budidaya rumput laut yang baik agar dapat menghasilkan kualitas yang baik. Selain itu masyarakat disadarkan bahwa perilaku menjaga kelestarian dan kebersihan pantai akan mendukung kegiatan budidaya yang mereka lakukan.

\section{UCAPAN TERIMA KASIH}

Tim pelaksana kegiatan pengabdian kepada masyarakat mengucapkan terima kasih Rektor Universitas Mataram sesuai dengan surat perjanjian nomor: 1231/UN18/LPPM/2018 tanggal 10 April 2018, karena dengan dana hibah inilah kegiatan dapat terlaksana dengan baik. Kami juga berterimakasish dengan segala pihak yang telah terlibat dan membantu kegiatan ini berjalan.

\section{DAFTAR PUSTAKA}

Dinas Kelautan dan Perikanan NTB. dislutkan.ntbprov.go.id/DATA\%20S TATISTIK\%20PERIKANAN\%20B UDIDAYA. [diakses 29 Maret 2018]. Junaidi, M. 2016. Pendugaan Limbah Organik Budidaya Udang Karang dalam Karamba Jaring Apung terhadap Kualitas Perairan Teluk Ekas Provinsi Nusa Tenggara Barat. J.Bio.Tropis. Vol.16(2):64-79.

Majid, A. 2018. Pertumbuhan rumput Laut Eucheuma cottonii pada kedalaman air laut yang berbeda di teluk ekas kecamatan Jerowaru, Lombok Timur.[Skripsi]. Program Studi Budidaya Perairan Universitas Mataram.

Pongarrang, D., A. Rahman, Wa iba. 2013. Pengaruh Jarak Tanam dan Bobot Bibit terhadap Pertumbuhan Rumput Laut (Kappaphycus alvarezii) menggunakan Metode Verticultur. J.Mina Laut Indonesia. Vol. 03 No. 12:94-112.

Radiarta, I N., S.E.Wardoyo., B. Priono., O. Praseno. 2003. Aplikasi Sistem Informasi Geografis untuk Penentuan Lokasi Pengembangan Budidaya Laut di Teluk Ekas, Nusa Tenggara Barat. J. PPI. Vol.9 (1):67-80. 